\title{
ADAPTATION OF COMPLETE DENTURE BASES SUBMITTED TO CHEMICAL POLISHING
}

\author{
ADAPTAÇÃO DE BASES DE PRÓTESES TOTAIS SUBMETIDAS A POLIMENTO QUÍMICO
}

\author{
Márcia GOMES ${ }^{1}$, Josué Ricardo BROILO ${ }^{1}$, Luiz Fernando WALBER ${ }^{2}$, \\ Paulo César Armani MACCARI ${ }^{3}$, Rosemary Sadami Arai SHINKAI ${ }^{4}$
}

\begin{abstract}
1- Undergraduate Student of Dental School, Pontifical Catholic University of Rio Grande do Sul, Porto Alegre, RS, Brazil.
2- DDS, MS, Assistant Professor, Department of Prosthodontics, Dental School, Pontifical Catholic University of Rio Grande do Sul and Federal University of Rio Grande do Sul, Porto Alegre, RS, Brazil.

3- DDS, MS, Assistant Professor, Department of Prosthodontics, Dental School, Pontifical Catholic University of Rio Grande do Sul, Porto Alegre, RS, Brazil.

4- DDS, MS, PhD, Associate Professor, Department of Prosthodontics, Dental School, Pontifical Catholic University of Rio Grande do Sul, Porto Alegre, RS, Brazil.
\end{abstract}

Corresponding address: Rosemary Sadami Arai Shinkai - Avenida Cristóvão Colombo 3084, cj 708/709 - Porto Alegre, RS. Cep.: 90560-002. Brazil. Tel.: (51) 3342-4780 - Email: rshinkai@pucrs.br

Received: March 05, 2004 - Returned for modification: April 19, 2004 - Accepted: July 08, 2004

\begin{abstract}
Q

bjective: This study evaluated the effect of chemical polishing on the internal adaptation of complete denture bases fabricated with Veracril ${ }^{\circledR}$ resin and polymerized by either the conventional (C) or microwave (M) techniques. Material and Methods: Six groups (n=6/group) were tested: 1) C + no polishing (CO); 2) C + chemical polishing (CQ); 3) C + immersion in hot water at $75^{\circ} \mathrm{C}(\mathrm{CW})$; 4) $\mathrm{M}+$ no polishing (MO); 5) $\mathrm{M}+$ chemical polishing (MQ); and 6) $\mathrm{M}+$ immersion in hot water at $75^{\circ} \mathrm{C}$ (MW). Internal adaptation immediately after the polishing treatment and after 30 days of storage in water at $37^{\circ} \mathrm{C}$ was evaluated by weighing a vinyl polysiloxane film reproducing the gap between resin base and metallic master model, using a precision scale. Data were analyzed by ANOVA and Tukey test and paired Student's t test, at a significance level of 0.05 . Results: No significant difference in immediate adaptation was found as a function of technique, polishing treatment, or interaction of technique/polishing. After 30 days, adaptation means (g) were: $\mathrm{CO}=2.46 \pm 0.32 \mathrm{a} ; \mathrm{CQ}=3.40 \pm 0.23 \mathrm{~d} ; \mathrm{CW}=3.14 \pm 0.22 \mathrm{c} ; \mathrm{MO}=3.23 \pm 0.37$ c, d; MQ=3.41 $\pm 0.47 \mathrm{~d} ; \mathrm{MW}=2.81 \pm 0.33 \mathrm{~b}$ (means followed by different letters are statistically different at $\alpha=0.05$ ). All groups but group CO had significant increase of misfit over the tested period. Conclusion: The present results suggest that Veracril@ resin denture bases submitted to chemical polishing had decrease of internal adaptation in 30 days, although immediate adaptation was not affected.
\end{abstract}

Uniterms: Acrylic resin, adaptation; Chemical polishing; Complete dentures.

\section{RESUMO}

bjetivo: Este trabalho avaliou o efeito do polimento químico sobre a adaptação interna de bases de próteses totais confeccionadas em resina acrílica ativada termicamente Veracril ${ }^{\circledR}$ polimerizada por técnica convencional (C) ou por microondas (M). MATERIAIS E MÉTODOS: Foram testados seis grupos (n=6/grupo): 1) C + sem polimento (CO); 2) C + polimento químico (CQ); 3) $\mathrm{C}+$ banho de água a $75^{\circ} \mathrm{C}(\mathrm{CW})$; 4) $\mathrm{M}+$ sem polimento (MO); 5) $\mathrm{M}$ + polimento químico (MQ); e 6) M + banho de água a $75^{\circ} \mathrm{C}(\mathrm{MW})$. A adaptação interna foi avaliada por pesagem em balança analítica de precisão de uma película de silicona de adição interposta entre base de resina e modelo-mestre metálico. A adaptação foi medida imediatamente após o polimento e após 30 dias de armazenamento em água a $37^{\circ} \mathrm{C}$. Os dados foram analisados por ANOVA e teste de Tukey, e por teste t de Student pareado, ao nível de significância de 0,05. RESULTADOS: Não houve diferença significativa na adaptação imediata em função do tipo de polimerização, do polimento ou da interação polimerização/polimento. Após 30 dias, as médias de adaptação (g) foram: $\mathrm{CO}=2,460,32 \mathrm{a}$; $\mathrm{CQ}=3,40 \pm 0,23 \mathrm{~d}$; $\mathrm{CW}=3,14 \pm 0,22 \mathrm{c} ; \mathrm{MO}=3,23 \pm 0,37 \mathrm{c}$, d; $\mathrm{MQ}=3,41 \pm 0,47 \mathrm{~d} ; \mathrm{MW}=2,81 \pm 0,33 \mathrm{~b}$ (médias seguidas por letras diferentes diferem entre si, $\alpha=0,05$ ). Todos os grupos apresentaram aumento significativo de desadaptação ao longo do tempo, com exceção do grupo CO. CONCLUSÃO: Os resultados sugerem que as bases de resina Veracril ${ }^{\circledR}$ submetidas a polimento químico apresentaram diminuição de adaptação interna em 30 dias, embora a adaptação imediata não tenha sido afetada.

Unitermos: Resina acrílica, adaptação; Polimento químico; Prótese total. 


\section{INTRODUCTION}

Internal adaptation of resin bases to the residual ridge is a fundamental requirement for the final success of complete dentures and may be compromised during the several phases of denture processing. Many materials and techniques have been proposed to obtain prostheses with better adaptation and resistance, including replacement of the conventional polymerization technique in hot water bath by alternative polymerization using microwave energy, injection molding, visible light, and dry heat ${ }^{4}$.

Microwave polymerization of acrylic resins is faster, easier, and cleaner than the conventional technique and may reduce the internal stresses in the resin bulk ${ }^{5,8}$. However, differences in the composition of the available resins may influence some mechanical properties, such as dimensional stability, microhardness, and porosity ${ }^{1,9,12,13}$. More recently, acrylic resins that are specially formulated to be heatpolymerized by either water bath or microwave energy were introduced as the resin evaluated in this study. Little is known about the impact of both polymerization techniques on this type of resin concerning tridimensional stability.

Another technical procedure that may interfere with denture adaptation is chemical polishing, since the process also occurs at the internal surface. Internal surfaces of complete dentures are not routinely polished by the mechanical polishing procedure, but a smoother surface in contact with the bearing mucosa would possibly benefit patients with impaired manual dexterity as it could facilitate removal of microorganisms and residues. Although faster and easier than the conventional mechanical polishing, some physicochemical properties of the acrylic resin are affected by this technique because of immersion in hot monomerbased liquid2,10,15,16. For a comprehensive evaluation of denture base materials and technical procedures, studies should also assess the internal adaptation of resin bases besides the physical properties. At present, it is unknown if the internal adaptation of resin bases is modified by chemical polishing or if this adaptation varies over time. Also, it is still unclear if the possible effect of chemical polishing on denture resins would arise because of the action of the chemicals in the liquid or because of an interaction of the liquid temperature $\left(75^{\circ} \mathrm{C}\right)$ as well.

Therefore, the aim of this study was to evaluate the effect of chemical polishing on the internal adaptation of acrylic resin denture bases polymerized by conventional or microwave techniques, immediately after the polishing procedure and after 30 days of storage.

\section{MATERIALAND METHODS}

Thirty-six specimens were made with the heatpolymerized poly (methyl methacrylate) resin Veracril ${ }^{\circledR}$ (New Stetic Dental Ltda, Petrópolis, RJ, Brazil). A vinyl polysiloxane impression (Elite Doublé, Zhermack, Rovigo, Italy) was obtained from a metallic master cast of an edentulous maxilla and poured with type III dental stone (Herodent, Vigodent
SA Ind Com, Rio de Janeiro, RJ, Brazil).

A denture baseplate with approximately 2-mm thickness was waxed up on each stone cast. The wax baseplate/cast sets were randomly divided into two groups for conventional or microwave polymerization. The samples to be polymerized by conventional technique were invested in metallic flasks, while the samples to be polymerized by microwave technique were invested in plastic flasks. The acrylic resin was prepared according to the manufacturer's recommendations by one investigator to prevent inter-subjects variation. The doughy resin was packed in the mould using a trial-technique with a wet cellophane film. Final packing was accomplished with a 1-ton pressure for $30 \mathrm{~min}$.

For resin processing, the metallic flasks were polymerized using a 3-hour conventional water bath $\left(90 \mathrm{~min}\right.$ to $65^{\circ} \mathrm{C}$ and 90 min to $95^{\circ} \mathrm{C}$ ) (Termotron P-100, Termotron Equipamentos, Piracicaba, SP, Brazil). The microwave plastic flasks were polymerized in a domestic microwave oven (LG Electronics, Model MS-115ML, São Paulo, SP, Brazil) according to the manufacturer's instructions (3 min to $345 \mathrm{~W}, 4 \mathrm{~min}$ to $0 \mathrm{~W}$, and $3 \mathrm{~min}$ to $690 \mathrm{~W}$ ). After bench cooling to room temperature, the flasks were opened, and the bases were deflasked and trimmed until the border limit of the master cast.

Within each polymerization group (conventional or microwave technique), the resin bases were randomly divided into three groups to receive the experimental treatment (no polishing, chemical polishing, or immersion in water at $75^{\circ} \mathrm{C}$ ). Chemical polishing was performed in a chemical polishing machine (PQ-9000 Termotron, Termotron do Brasil Ltda, Piracicaba, Brazil) by immersion in a special liquid (methylmethacrylate monomer plus hydroquinone) at $75^{\circ} \mathrm{C}$ for $10 \mathrm{~s}$. After that, they were allowed to dry over the bench for $15 \mathrm{~s}$ and then washed in running tap water for $15 \mathrm{~s}$. The groups of immersion in hot water consisted of immersing the resin bases in water at $75^{\circ} \mathrm{C}$ for $10 \mathrm{~s}$.

Therefore, six groups ( $n=6 /$ group) were obtained: conventional technique, no polishing (CO); conventional technique, chemical polishing (CQ); conventional technique, immersion in hot water at $75^{\circ} \mathrm{C}(\mathrm{CW})$; microwave technique, no polishing (MO); microwave technique, chemical polishing (MQ); and microwave technique, immersion in hot water at $75^{\circ} \mathrm{C}(\mathrm{MW})$. These groups were coded with random letters to blind the examiner during the adaptation measurement.

Internal adaptation was evaluated immediately after the polishing treatment and after 30 days of storage in water at $37^{\circ} \mathrm{C}$ by weighing a silicone film reproducing the gap between resin base and metallic master model ${ }^{6}$. A standardized portion of flow type vinyl polysiloxane (3M ESPE Express, St. Paul, MN, USA) was prepared and coated the internal surface of each resin base, which was adapted to the master cast under an axial load of $4 \mathrm{kgf}$. After polymerization of the silicone, the resulting silicone film was trimmed at the borderline mark of the master cast and weighed using a precision scale with accuracy of $0.0001 \mathrm{~g}$ (Mettler Toledo, model AG204, Switzerland). This procedure was done in duplicate for each specimen, and the average value was recorded as the specimen internal adaptation. 
Sample size was calculated based on data from a pilot study, considering an acceptable error of $0.15 \mathrm{~g}$ (approximately $6.6 \%$ of the mean value of adaptation) and the $95 \%$ confidence level. Data were analyzed using SPSS 11.5 by means of two-way ANOVA (polymerization $\mathrm{x}$ polishing) and Tukey test at a significance level of 5\% (twotailed). Data of immediate adaptation and adaptation after 30 days of storage in water were analyzed by paired Student's $\mathrm{t}$ test at a significance level of 5\% (two-tailed).

\section{RESULTS}

Internal adaptation mean values ranged from $2.10 \mathrm{~g}$ to 3.41g. Table 1 shows the means and standard deviations of the adaptation values for each experimental group. Preliminary analyses confirmed the assumptions for ANOVA. In relation to immediate adaptation, no statistically significant difference was found as a function of Polymerization technique ( $\mathrm{P}=0.658$ ), Polishing procedure $(\mathrm{P}=0.550)$, or interaction Polymerization/Polishing $(\mathrm{P}=0.349)$.

Regarding adaptation after 30 days of storage in water, the main factor Polishing procedure $(\mathrm{P}<0.001)$ and the interaction Polymerization/Polishing $(\mathrm{P}=0.001)$ were statistically significant. Statistically different groups were detected by Tukey test at a significance level of 0.05 . When comparing the immediate adaptation and the adaptation after 30 days within each group, all groups but $\mathrm{CO}(\mathrm{P}=0.575)$ had significant increase of mean values (Table 1$)$.

\section{DISCUSSION}

Chemical polishing represents an attractive alternative procedure to mechanical polishing using slurry of pumice and water because it is timesaving and easy to perform. However, previous studies have shown that chemical polishing may reduce surface hardness ${ }^{2,15,16}$ and transverse strength $^{11}$, and increase residual monomer content ${ }^{2}$, impact strength $^{10}$ and resin solubility ${ }^{15}$. Internal adaptation of dentures would also be affected by chemical polishing because of the potential resin distortion and surface modification.

The results of this study for immediate adaptation evaluation after the experimental treatment showed no difference as a function of polymerization technique or chemical polishing. According to the manufacturer, the poly (methyl methacrylate) used has cross-linked chains, which may provide greater dimensional stability. Also, chemical polishing does not seem to promote a significant surface wear on the internal surface as the resin bases submitted to this type of chemical polishing did not differ from the bases with no polishing.

Potential influence of the temperature of the chemical polishing solution on increased release of the resin internal stresses was raised previously ${ }^{16}$. Craig ${ }^{4}$ (1997) reports heat distortion when acrylic resins are heated from 71 to $90^{\circ} \mathrm{C}$. However, the similar adaptation pattern exhibited by the groups submitted to hot water bath at the same temperature of the chemical polishing solution $\left(75^{\circ} \mathrm{C}\right)$ demonstrates that the polishing solution temperature did not affect immediate adaptation. This may be explained by the short immersion period of the resin bases (10 seconds), which would not be sufficient to promote any significant distortion caused by heat.

Although immediate adaptation was similar, after 30 days of storage in water all groups but group CO had significant poorer internal adaptation. Self- and heat-polymerized acrylic resins may have changes in dimensional stability when stored in water, independently of the type of resin or polymerization technique ${ }^{7}$. Resin expansion is expected with storage in most solutions because of sorption of water ${ }^{4}$ and could explain the increasing values of misfit between resin base and master cast.

Resin bases that were polymerized by the conventional technique and not submitted to chemical polishing nor hot water bath had the best dimensional stability over the test period. On the other hand, the chemical polishing groups

TABLE 1- Immediate adaptation, adaptation after 30 days of storage in water at $37^{\circ} \mathrm{C}$, and variation of adaptation for each group $(n=6)$

\begin{tabular}{lcccc}
\hline Group & Immediate adaptation (g) & Adaptation 30 days (g) & Variation (\%) & $\mathbf{P}$ * \\
\hline CO & $2.33 \pm 0.38$ & $2.46 \pm 0.32 \mathrm{a}$ & 5.58 & 0.575 \\
$\mathrm{CQ}$ & $2.10 \pm 0.39$ & $3.40 \pm 0.23 \mathrm{~d}$ & 61.90 & $<.001$ \\
$\mathrm{CW}$ & $2.49 \pm 0.26$ & $3.14 \pm 0.22 \mathrm{c}$ & 26.10 & $<.001$ \\
$\mathrm{MO}$ & $2.42 \pm 0.65$ & $3.23 \pm 0.37 \mathrm{c}, \mathrm{d}$ & 33.47 & 0.019 \\
MQ & $2.37 \pm 0.27$ & $3.41 \pm 0.47 \mathrm{~d}$ & 43.88 & $<.001$ \\
MW & $2.36 \pm 0.40$ & $2.81 \pm 0.33 \mathrm{~b}$ & 19.07 & 0.036 \\
\hline
\end{tabular}

Immediate adaptation: No significant difference between groups at the significance level of 0.05.

Adaptation 30-days: Means followed by different letters are statistically different at $\alpha=0.05$.

* Paired Student's t test for Immediate adaptation versus Adaptation 30 days, $\alpha=0.05$. 
showed the highest absolute values after 30 days and also the highest variation of internal adaptation. An increased water sorption by the chemically polished bases might be an explanation for this behavior. Braun et al. ${ }^{2}$ (2003) suggest that the resin structure is modified with the chemical polishing, which would dissolve the polymer chains of the polymerized acrylic resins. This degradation could cause accelerated aging of the material. It also is possible that more amounts of internal stresses are released over time when the chemical polishing is applied. Therefore, chemical polishing would promote a less favorable result of internal adaptation over time because of the potential alteration of the resin structure and surface.

Additionally, other factors may affect the internal adaptation of resin bases submitted to chemical polishing. For instance, Sadamori, et al. ${ }^{14}$ (1997) observed different amounts of linear changes as a function of resin thickness, which suggests that internal adaptation of denture bases may vary according to the resin volume. This study evaluated bases of approximately 2-mm thickness, which represents the average thickness of the central palatal area in the posterior region. The measurement of base misfit in this posterior area using microscopy is higher than in other basal areas ${ }^{3}$. Thicker bases submitted to surface treatment and heat exposure by the chemical polishing solution might have different dimensional behavior from the present results. Therefore, further studies should investigate the effect of chemical polishing on different thickness of the resin base. Also, it would be interesting to compare the global internal adaptation results measured by the silicone film weighing technique with punctual microscopic measurements of adaptation.

It is necessary to consider that, although statistically different, inter-group adaptation values varied in the magnitude of tenth of gram, which may not represent a fundamental clinical problem if optimal support and saliva conditions are present. The lack of perfect adaptation is distributed along the basal area and may be compensated by the saliva film and mucosa resilience when dentures are in service. However, in adverse clinical conditions for denture retention, such as highly resorbed ridges, very low salivary flow rates, and motor incoordination, optimal adaptation is desirable and chemical polishing may not be recommended for the resin evaluated in this study. Further studies with longer evaluation of internal adaptation of denture bases fabricated with different materials and assessment of the impact of adaptation values on clinical outcomes are warranted.

\section{CONCLUSION}

The present results suggest that complete denture bases made with Veracril ${ }^{\circledR}$ resin and submitted to chemical polishing showed decrease of internal adaptation in 30 days, although immediate adaptation was not affected.

\section{REFERENCES}

1- Blagojevic V, Murphy VM. Microwave polymerization of denture base materials. A comparative study. J Oral Rehabil 1999;26:804-8.

2- Braun KO, Mello JAN, Rached RN, Del Bel Cury AA. Surface texture and some properties of acrylic resins submitted to chemical polishing. J Oral Rehabil 2003;30:91-8.

3- Consani RLX, Domitti SS, Rizzatti Barbosa CM, Consani S. Effect of commercial acrylic resins on dimensional accuracy of the maxillary denture base. Braz Dent J. 2002;13:57-60.

4- Craig RC. Prosthetic applications of polymers. In: Craig RC, editor. Restorative dental materials. 10th ed. Saint Louis: Mosby; 1997. p.500-51.

5- De Clerck JP. Microwave polymerization of acrylic resins used in dental prostheses. J Prosthet Dent 1987;57:650-8.

6- Ganzarolli SM, Rached RN, Garcia RC, Del Bel Cury AA. Effect of cooling procedure on final denture base adaptation. J Oral Rehabil 2002;29:787-90.

7- Ganzarolli SM. Avaliação da adaptação, porosidade, resistência flexural e ao impacto de resinas acrílicas. Piracicaba; 2001. [Tese de Doutorado - Universidade Estadual de Campinas].

8- Hayden WJ. Flexural strength of microwave-polymerized denture baseplates. Gen Dent 1986;34:367-71.

9- Keenan PL, Radford DR, Clark RK. Dimensional change in complete dentures fabricated by injection molding and microwave processing. J Prosthet Dent 2003;89:37-44.

10- Mesquita MF, Domitti SS, Consani S, Cardoso LAM, Góes MF. Efeito do polimento químico sobre a resistência ao impacto das resinas acrílicas. Semina Ciênc Biol/Saúde 1996;17:178-82.

11- Nunes de Mello JA, Braun KO, Rached RN, Del Bel Cury AA. Reducing the negative effects of chemical polishing in acrylic resins by use of an additional technique of polymerization. J Prosthet Dent 2003;89:598-602.

12- Rizzati-Barbosa CM, Nadin PS, Del Bel Cury AA, RodriguezGarcia RCM. Uso de la energía de microondas en el procesamiento de prótesis odontológicas. Rev. Asoc. Odontol. Argent 1998;86:105-8.

13- Rodrigues-Garcia RC, Del Bel-Cury AA. Accuracy and porosity of denture bases submitted to two polymerization techniques. Indian J Dent Res 1996;7:122-6.

14- Sadamori S, Ishii T, Hamada T. Influence of thickness on the linear dimensional change, warpage, and water uptake of a denture base resin. Int J Prosthodont 1997;10:35-43.

15- Samuel SM, Selistre CR. Avaliação da influência do polimento químico na sorpção, solubilidade e microdureza de uma resina acrílica de termopolimerização. R Fac Odontol Porto Alegre 2000;41:8-13.

16- Stolf WL, Consani S, Ruhnke LA. Reflexão das resinas acrílicas sob influência dos polimentos químico e mecânico. Rev Paul Odontol 1986;8:18-22. 